\title{
Investigation of Indoor Air Quality and Staff Satisfaction in Underground Buildings in Xi'an, China
}

\author{
Xin Zhang ${ }^{1 *}$, Yuesheng Fan ${ }^{1 * *}$, Wanqing Yu${ }^{1}$, Huan Wang ${ }^{1}$, Feilong Zhao ${ }^{2}$, \\ Haitao Tao ${ }^{3}$, Zeming F ${ }^{1}$ \\ ${ }^{1}$ School of Building Services Science and Engineering, Xi'an University of Architecture and Technology, \\ No.13 Yanta Road, Xi'an, Shaanxi, China, 710055 \\ ${ }^{2}$ China Railway Eryuan Engineering Group East China Survey and Design Co., Ltd. Hangzhou, China \\ ${ }^{3}$ Zhongjiao No.1 Highway Reconnaissance Design Research Institute Co., Ltd. Xi'an, China
}

Received: 1 October 2020

Accepted: 28 November 2020

\begin{abstract}
With the widespread promotion of underground buildings, it is necessary to know the status of indoor air quality of underground buildings. In this study, indoor air quality was tested from 9 sites of three styles underground buildings in Xi'an. Simultaneously, a questionnaire survey was conducted with indoor staff satisfaction. The results showed the concentrations of pollutants in 9 sites except for $\mathrm{CO}$ were all exceeding the standard. The concentrations of formaldehyde, $\mathrm{PM}_{10}, \mathrm{CO}_{2}$, and TVOC all exceeded the standard of 1.26, 1.62, 1.28, and 1.66 times. Pollutions were the most serious in underground shopping malls, followed by underground snack cities and underground electronic cities. $\mathrm{PM}_{10}$ and TVOC were the most prominent pollutants, followed by formaldehyde. Indoor air quality of underground shopping malls was the worst satisfaction with people. Indoor air quality of underground electronic cities was satisfied. Satisfaction limit of formaldehyde was lower than the standard value. Satisfaction limit of TVOC was higher than the standard value. Satisfaction limit of $\mathrm{PM}_{10}$ was slightly higher than the standard value, and satisfaction limit of $\mathrm{CO}_{2}$ was close in line with the standard value. It would contribute to the development and application of underground buildings.
\end{abstract}

Keywords: air pollutants, objective evaluation, underground buildings, Xi'an

\section{Introduction}

With the rapidly rising number of underground buildings in recent years, people pay more and more attention to the development of urban underground

*e-mail: 2601084634@qq.com

**e-mail: fanyuesheng@xauat.edu.cn space [1-2]. Many underground public buildings have been constructed in various countries around the world such as tunnels [3], subway stations [4, 5], underground shopping malls [6]. China has also achieved significant development [7]. But at the same time, the indoor air quality of underground buildings was equally worrying. Relevant literature showed that pollutants in underground space mainly included TVOC (Total 
Volatile Organic Compounds), CO (carbon monoxide), $\mathrm{PM}_{10}$ (Particulate matter $\left.10 \mu \mathrm{m}\right)$, formaldehyde ( $\mathrm{HCHO}$ ), radioactive tritium, etc [8]. The concentrations of different pollutants in underground buildings in some parts of China from existing researchers all exceeded the standards now [9]. Like formaldehyde and TVOC [10], and CO [11], they would cause different degrees of danger for people health $[12,13]$. Such as respiratory diseases [14], hypersensitive diseases [15], and even death [16].

The results of existing evaluations for pollutants usually considered only one factor of testing. However, both of the pollutant concentrations and human subjective feelings need to be considered comprehensively for indoor air quality [17, 18]. Domestic indoor health standards mainly set pollutant concentration limits from the basic of human health now. It rarely involves the subjective feelings of people indoors. The poor IEQ (Indoor Environment Quality) not only may affect both customer comfort and employee productivity, but also affects the emotions and purchase decisions of customers [19]. The results of indoor air quality in shopping malls in some areas of China showed the dissatisfaction rates were exceeded $20 \%$ [20]. The relationship between pollutants and air quality satisfaction should be given by the limits of pollutants based on the dissatisfaction rate of people indoors [21]. But, the existing research was rarely able to consider the human health and human satisfaction at the same time [22]. In addition, people spend more time in underground buildings, the quality of underground indoor environment would affect people's health directly. The study of the human subjective feelings and the limits of pollutant concentrations needed to be considered comprehensively was not enough.

People may spend as much as $80-90 \%$ of their time indoors [23]. It is important to know the indoor comprehensive conditions of underground buildings. Indoor air quality of underground buildings was given through a combination of on-site testing and human satisfaction in this paper. It will provide a great significance to improve the indoor air quality of underground buildings.

\section{Methods}

Time of winter study was from December 10 to 25 , 2013, and it was from June 15 to 27, 2014 in summer. Nine underground buildings in Xi'an were tested. Types of those included underground shopping malls, underground snack cities, and underground electronic cities were shown in Fig. 1. The conditions were continuously monitored in the underground buildings during business hours (10:00-12:00, 14:00-18:00). Indoor temperature, humidity, $\mathrm{CO}, \mathrm{CO}_{2}$, TVOC, formaldehyde and $\mathrm{PM}_{10}$ were all tested the same time. The sampling point was set in areas with high personal density. Heights of sampling were at the breathing zone of the crowd (1.2 to $1.5 \mathrm{~m})$.

Indoor temperature, humidity, $\mathrm{CO}$, and $\mathrm{CO}_{2}$ were all tested by IAQ-calc7545 indoor air quality detector. Temperature range is $0 \sim 60^{\circ} \mathrm{C}$. Measuring accuracy is $\pm 0.6^{\circ} \mathrm{C}$. Relative humidity range is $5 \sim 95 \% \mathrm{RH}$. Measuring accuracy is $\pm 3.0 \% \mathrm{RH}$. Range of $\mathrm{CO}_{2}$ is $0 \sim 5000 \mathrm{ppm}$. Measuring accuracy is $\pm 3.0 \%$ or $\pm 50 \mathrm{ppm}$ of reading. Range of $\mathrm{CO}$ is $0 \sim 500 \mathrm{ppm}$. Measuring accuracy is $\pm 3.0 \%$ or $\pm 3 \mathrm{ppm}$ of reading. TVOC was used by PGM-7600K volatile gas detector. Range of it is $0.1 \sim 15000 \mathrm{ppm}$. Measuring accuracy is 10 2000 ppm: $\pm 3 \%$ of the calibration point. Formaldehyde was measured by Z-300XP formaldehyde detector. Range of it is 0 -30 ppm. Measuring accuracy is $\pm 5 \%$. $\mathrm{PM}_{10}$ was tested by GRIMM1.109 Portable Aerosol Spectrometer. Mass concentration range is $0.1 \sim 100000 \mu \mathrm{g} / \mathrm{m}^{3}$, and the repeatability is $5 \%$. This article referred to the standards for comprehensive reference [24, 25]. They gave the concentration limit of each pollutant (CO: $10 \mathrm{mg} / \mathrm{m}^{3} ; \quad \mathrm{CO}_{2}$ : $0.10 \%$; TVOC: $0.60 \mathrm{mg} / \mathrm{m}^{3}$; formaldehyde: $\left.0.10 \mathrm{mg} / \mathrm{m}^{3} ; \mathrm{PM}_{10}: 0.150 \mathrm{mg} / \mathrm{m}^{3}\right)$. The subjective survey was referred to the relevant literature [26], and a questionnaire form of human subjective evaluation of satisfaction was adopted. The content included: the quality of indoor air, the freshness of the air at the location, and the severity of various odors. Whether the people were satisfied in this environment, etc. That was (Very dissatisfied: -3 , Fairly dissatisfied: -2, Slight dissatisfied: -1 , Neutral: 0 , Slight satisfied: +1 , Fairly satisfied: +2 , Very satisfied: +3 ). a)

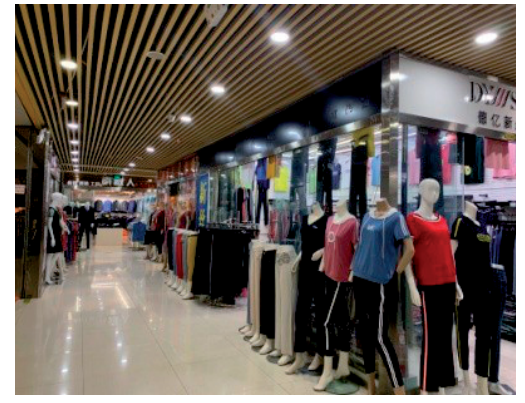

b)

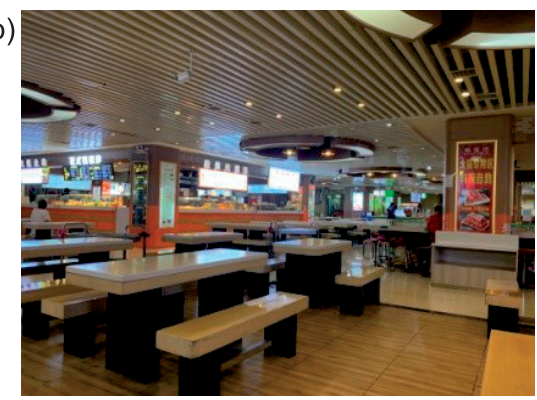

c)

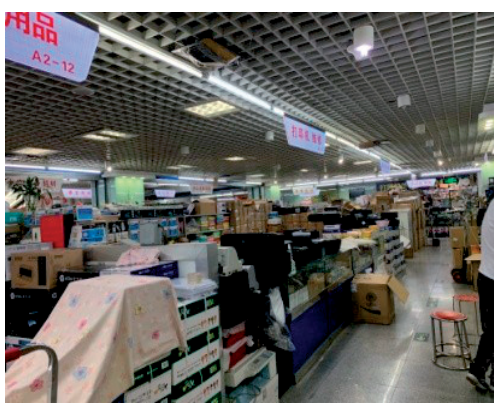

Fig. 1. Physical drawings of three typical underground buildings: a) underground shopping malls, b) underground snack cities, c) underground electronic cities. 


\section{Results and Discussion}

\section{Results of Pollutants}

The results showed the average indoor concentrations of formaldehyde, $\mathrm{PM}_{10}, \mathrm{CO}_{2}$, TVOC, and $\mathrm{CO}$ were $0.126 \mathrm{mg} / \mathrm{m}^{3}, 0.244 \mathrm{mg} / \mathrm{m}^{3}, 0.128 \%, 0.995 \mathrm{mg} / \mathrm{m}^{3}$, and $4.13 \mathrm{mg} / \mathrm{m}^{3}$. The concentrations of formaldehyde, $\mathrm{PM}_{10}$, $\mathrm{CO}_{2}$, and TVOC exceeded the standard of 1.26, 1.62, 1.28 , and 1.66 times, respectively. The concentrations of TVOC were the worst, it was consistent with the literature $[26,27]$. Among the three types of buildings, air pollution in underground shopping malls was the most serious. Average multiples of formaldehyde, $\mathrm{PM}_{10}$, $\mathrm{CO}_{2}$, and TVOC exceeded the standard of 1.98, 1.86, 1.49 , and 2.16 times, respectively. The most severe was still TVOC, it was consistent with the literature [28]. The details were shown in Table 1 .

\section{Relationship between Monitoring Data and Season}

Fig. 2a) shows the average concentration of $\mathrm{CO}$ in nine underground buildings did not exceed the limit set by the standard. The highest average concentration was in C-3, and it was $6.72 \mathrm{mg} / \mathrm{m}^{3}$. Relevant literature showed the content of $\mathrm{CO}$ in cigarette smoke produced by smoking was the highest [26]. There were few smokers in the testing at that time, and the concentration of $\mathrm{CO}$ could keep in a lower range.

Fig. 2b) shows the average concentration of $\mathrm{CO}_{2}$ in underground shopping malls and the underground snack cities all exceeded the standard. The average concentration of that in underground electronic cities did not exceed the standard at the same time [26]. This was because the large flow of people in the underground shopping malls and the underground snack cities [20]. The average concentrations of A-1, A-2, and A-3 were $0.157 \%, 0.143 \%$, and $0.149 \%$, respectively. They exceeded the standards by $1.57,1.43$, and 1.49 times, respectively. The average concentrations of $\mathrm{C}-1, \mathrm{C}-2$, and C-3 were $0.112 \%, 0.135 \%$, and $0.193 \%$, respectively. They exceeded the standards by $1.12,1.35$, and 1.93 times, respectively. The highest concentration of $\mathrm{CO}_{2}$ was $\mathrm{C}-3$, which exceeded the standard more seriously.

Fig. 2c) shows the average concentration of TVOC in underground shopping malls and underground snack cities were more serious [26]. The average concentration of that in underground electronic cities was near the standard limit. The average concentrations of A-1, A-2, and A-3 were $1.48 \mathrm{mg} / \mathrm{m}^{3}, 1.25 \mathrm{mg} / \mathrm{m}^{3}$, and $1.16 \mathrm{mg} / \mathrm{m}^{3}$, respectively. They exceeded the standards by $2.46,2.09$, and 1.93 times, respectively. The average concentrations of C-1, C-2, and C-3 were $0.921 \mathrm{mg} / \mathrm{m}^{3}, 1.04 \mathrm{mg} / \mathrm{m}^{3}$, and $1.23 \mathrm{mg} / \mathrm{m}^{3}$, respectively. They exceeded the standards by $1.54,1.73$, and 2.05 times, respectively. The average concentrations of underground shopping malls exceeded the standards seriously. There were many leather goods, cosmetics, and other products with high VOCs content in underground shopping malls. Another reason was that there were many people in shopping time [10, 26]. The main reason for the underground snack cities to exceed the standard was the indoor food packaging and cooking oil fume. There were mainly electronic

Table 1. Statistical data of each pollutant (temperature: $22.7 \sim 25.5^{\circ} \mathrm{C}$, humidity $34.9 \sim 43.1 \%$ ).

\begin{tabular}{|c|c|c|c|c|c|c|c|c|c|c|}
\hline \multirow{2}{*}{ Location } & \multicolumn{2}{|c|}{$\begin{array}{l}\text { Formaldehyde (mg/ } \\
\left.\qquad \mathrm{m}^{3}\right)\end{array}$} & \multicolumn{2}{|c|}{$\mathrm{PM}_{10}\left(\mathrm{mg} / \mathrm{m}^{3}\right)$} & \multicolumn{2}{|c|}{$\mathrm{CO}_{2}(\%)$} & \multicolumn{2}{|c|}{ TVOC $\left(\mathrm{mg} / \mathrm{m}^{3}\right)$} & \multicolumn{2}{|c|}{$\mathrm{CO}\left(\mathrm{mg} / \mathrm{m}^{3}\right)$} \\
\hline & Average & Range & Average & Range & Average & Range & Average & Range & Average & Range \\
\hline A-1 & 0.220 & $0.211 \sim 0.228$ & 0.299 & $0.279 \sim 0.319$ & 0.157 & $0.144 \sim 0.169$ & 1.48 & $1.307 \sim 1.643$ & 5.21 & $4.75 \sim 5.68$ \\
\hline A-2 & 0.175 & $0.172 \sim 0.178$ & 0.268 & $0.264 \sim 0.271$ & 0.143 & $0.128 \sim 0.157$ & 1.25 & $1.132 \sim 1.372$ & 4.27 & $2.32 \sim 6.22$ \\
\hline A-3 & 0.199 & $0.196 \sim 0.202$ & 0.271 & $0.251 \sim 0.291$ & 0.149 & $0.161 \sim 0.137$ & 1.16 & $1.038 \sim 1.278$ & 2.64 & $2.64 \sim 2.65$ \\
\hline Average & 0.198 & $0.172 \sim 0.228$ & 0.279 & $0.251 \sim 0.319$ & 0.149 & $0.128 \sim 0.169$ & 1.30 & $1.038 \sim 1.643$ & 4.04 & $2.32 \sim 6.22$ \\
\hline B-1 & 0.073 & $0.064 \sim 0.082$ & 0.194 & $0.175 \sim 0.212$ & 0.089 & $0.079 \sim 0.098$ & 0.633 & $0.593 \sim 0.673$ & 1.73 & $1.10 \sim 2.36$ \\
\hline B-2 & 0.073 & $0.071 \sim 0.075$ & 0.170 & $0.139 \sim 0.201$ & 0.090 & $0.088 \sim 0.091$ & 0.701 & $0.697 \sim 0.705$ & 2.40 & $2.26 \sim 2.55$ \\
\hline B-3 & 0.052 & $0.042 \sim 0.061$ & 0.171 & $0.147 \sim 0.194$ & 0.083 & $0.079 \sim 0.086$ & 0.554 & $0.502 \sim 0.605$ & 3.67 & $3.33 \sim 4.01$ \\
\hline Average & 0.066 & $0.042 \sim 0.082$ & 0.178 & $0.139 \sim 0.212$ & 0.087 & $0.079 \sim 0.098$ & 0.629 & $0.502 \sim 0.705$ & 2.60 & $1.10 \sim 4.01$ \\
\hline $\mathrm{C}-1$ & 0.099 & $0.082 \sim 0.115$ & 0.218 & $0.182 \sim 0.254$ & 0.112 & $0.105 \sim 0.118$ & 0.921 & $0.919 \sim 0.923$ & 4.76 & $3.29 \sim 6.24$ \\
\hline $\mathrm{C}-2$ & 0.100 & $0.097 \sim 0.102$ & 0.264 & $0.221 \sim 0.307$ & 0.135 & $0.131 \sim 0.139$ & 1.04 & $0.964 \sim 1.107$ & 5.76 & $5.25 \sim 6.26$ \\
\hline $\mathrm{C}-3$ & 0.142 & $0.137 \sim 0.146$ & 0.340 & $0.317 \sim 0.363$ & 0.193 & $0.182 \sim 0.203$ & 1.23 & $1.154 \sim 1.302$ & 6.72 & $6.12 \sim 7.33$ \\
\hline Average & 0.113 & $0.082 \sim 0.146$ & 0.274 & $0.182 \sim 0.363$ & 0.146 & $0.105 \sim 0.203$ & 1.06 & $0.919 \sim 1.302$ & 5.75 & $3.29 \sim 7.33$ \\
\hline Average & 0.126 & $0.042 \sim 0.228$ & 0.244 & $0.139 \sim 0.319$ & 0.128 & $0.079 \sim 0.169$ & 0.995 & $0.502 \sim 1.302$ & 4.13 & $1.10 \sim 7.33$ \\
\hline
\end{tabular}

Note: Underground shopping malls: A-1, A-2, A -3. Underground electronic cities: B-1, B-2, B-3. Underground snack cities: C-1, C-2, C-3. 

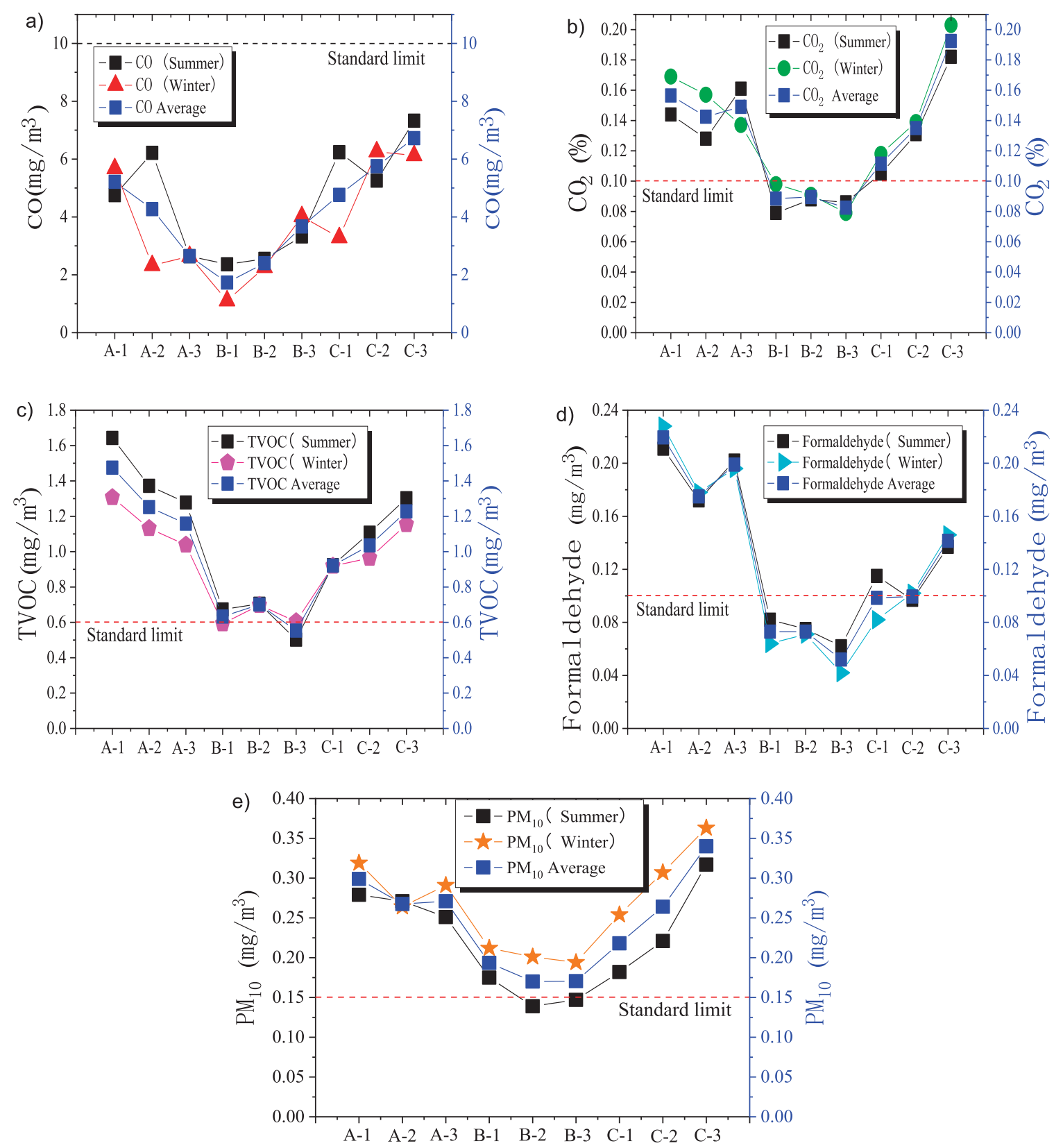

Fig. 2. Average concentration of pollutants in various underground buildings: a) $\mathrm{CO}$ in summer and winter, b) $\mathrm{CO}_{2}$ in summer and winter, c) TVOC in summer and winter, d) Formaldehyde in summer and winter, e) $\mathrm{PM}_{10}$ in summer and winter.

products of underground electronic cities, and the average concentrations of that were low.

Fig. 2d) shows the average concentration of formaldehyde in underground shopping malls was more serious than the standard. The average concentration of that in underground electronic cities did not exceed the standard, but the average concentration of C-3 was exceeded the standard [26]. Among them, the average concentrations of A-1, A-2, A-3 were $0.220 \mathrm{mg} / \mathrm{m}^{3}$, $0.175 \mathrm{mg} / \mathrm{m}^{3}$, and $0.199 \mathrm{mg} / \mathrm{m}^{3}$, respectively. They exceeded the standards by $2.20,1.75$, and 1.99 times, respectively. Leather goods, clothing and other products would contact with air to emit much formaldehyde [10]. The average concentration of C-3 was $0.142 \mathrm{mg} / \mathrm{m}^{3}$, and it was exceeded the standard by 1.42 times. The main reason for underground snack city was renovated soon after it was put into use. Many adhesives would release more formaldehyde at that time [10]. The average concentrations of formaldehyde in summer were significantly higher than that in winter.

Fig. 2e) shows the average concentration of $\mathrm{PM}_{10}$ exceeded the standard. The range of exceeding the standard value was from 1.13 times to 2.27 times. The average concentrations of $\mathrm{PM}_{10}$ in underground snack cities and underground shopping malls were all serious [26]. Relevant literature showed that $\mathrm{PM}_{10}$ was usually positively related to the flow of people [29]. There was a high average concentration of $\mathrm{PM}_{10}$ in underground shopping malls and underground snack cities because of the large flow of people. The underground snack cities 
Table 2. Comprehensive evaluation of indoor air quality of various buildings.

\begin{tabular}{|c|c|c|c|c|c|}
\hline \multirow{2}{*}{ Location } & \multirow{2}{*}{ Aggregative index(I) } & \multicolumn{2}{|c|}{ Maximum Quality Index $\left(\mathrm{I}_{\max }\right)$} & \multirow{2}{*}{ Air Quality Index Level } & \multirow{2}{*}{ Air Pollution Level } \\
\hline & & Pollutants & Results & & \\
\hline A-1 & 2.07 & TVOC & 2.46 & $\mathrm{~V}$ & Heavily Polluted \\
\hline A-2 & 1.77 & TVOC & 2.09 & IV & Moderately Polluted \\
\hline A-3 & 1.70 & TVOC & 1.93 & IV & Moderately Polluted \\
\hline Average & 1.84 & TVOC & 2.16 & IV & Moderately Polluted \\
\hline B-1 & 1.03 & $\mathrm{PM}_{10}$ & 1.29 & III & Lightly Polluted \\
\hline B-2 & 0.99 & TVOC & 1.17 & II & Uncontaminated \\
\hline B-3 & 0.93 & $\mathrm{PM}_{10}$ & 1.14 & II & Uncontaminated \\
\hline Average & 0.97 & $\mathrm{PM}_{10}$ & 1.19 & II & Uncontaminated \\
\hline $\mathrm{C}-1$ & 1.31 & TVOC & 1.54 & III & Lightly Polluted \\
\hline $\mathrm{C}-2$ & 1.50 & $\mathrm{PM}_{10}$ & 1.76 & IV & Moderately Polluted \\
\hline $\mathrm{C}-3$ & 1.94 & $\mathrm{PM}_{10}$ & 2.67 & IV & Moderately Polluted \\
\hline Average & 1.57 & $\mathrm{PM}_{10}$ & 1.83 & IV & Moderately Polluted \\
\hline
\end{tabular}

Note: Underground shopping malls: A-1, A-2, A -3. Underground electronic cities: B-1, B-2, B-3. Underground snack cities: C-1, C-2, C-3.

itself also produced most particulate matter due to the combustion of a large amount of fuel [30]. Therefore, it could be seen that $\mathrm{PM}_{10}$ was also one of the prominent pollutants in underground buildings.

\section{Objective Assessment of Indoor Air Quality}

Comprehensive pollution index method [27, 31], and combined with the standard of indoor air quality [24] were all used to objectively evaluate indoor air quality in this paper. The comprehensive pollution index method was taken the measured pollutant concentration value $C_{i}$ (average value) as the objective evaluation index. Inverse of the standard concentration limit $\mathrm{S}_{\mathrm{i}}$ of the pollutant was as a weighting factor to calculate the sub-index $\mathrm{C}_{\mathrm{i}} / \mathrm{S}_{\mathrm{i}}\left(\mathrm{I}_{\mathrm{i}}\right)$ of each pollutant, and the maximum value $\left(\mathrm{I}_{\mathrm{max}}\right)$ was selected from it by comparison. Then calculate the average value $\left(\mathrm{I}_{\mathrm{av}}\right)$ of the i pollutant quality sub-index. The geometric mean of the two is the air quality index (I). The mathematical expression is as follows [31].

$$
\mathrm{I}=\sqrt{\mathrm{I}_{\max } \times \mathrm{I}_{\mathrm{av}}}=\sqrt{\max \left[\frac{\mathrm{C}_{1}}{\mathrm{~S}_{1}}, \frac{\mathrm{C}_{2}}{\mathrm{~S}_{2}}, \cdots \frac{\mathrm{C}_{\mathrm{k}}}{\mathrm{S}_{\mathrm{k}}}\right] *\left[\frac{1}{\mathrm{k}} \sum_{\mathrm{i}=1}^{\mathrm{k}} \frac{\mathrm{C}_{\mathrm{i}}}{\mathrm{S}_{\mathrm{i}}}\right]}
$$

The degree of indoor air pollution could be evaluated according to the calculated comprehensive pollution index I. The greater the value of I was, the more serious the comprehensive pollution was. Results of indoor air quality comprehensive evaluation of 9 underground buildings were shown in Table 2 .

Pollution was the most serious in underground shopping malls. A-1 was the most polluted, A-2 and
A-3 were both moderately polluted. The average of them was moderately polluted. The second was the underground snack cities. C-1 was light polluted, C-2 and C-3 were moderately polluted. The average of them was moderately polluted. The pollution of underground electrical cities was lighter than those of others. B-1 was the lightly polluted, B-2 and B-3 were both uncontaminated. The average of them was uncontaminated. The largest indoor pollutants in the nine underground buildings were mainly the TVOC and $\mathrm{PM}_{10}$. In addition, formaldehyde could not be ignored. It might be connected to the poor ventilation effect of the underground building $[10,26]$. The haze weather in winter in Xi'an would also make the concentration of pollutant increased more quickly. It was necessary to increase the environmental sanitation of underground buildings in the later stage, especially to strengthen ventilation and air filter purification [32, 33].

\section{Relationship between Human Satisfaction and Concentration of Various Pollutants}

There were 514 questionnaires in this study, 263 in winter and 251 in summer. The ratio of male to female was nearly 1: 2 . It was about $80 \%$ between 26 and 35 years old, about $10 \%$ under the age of 26 , and another $10 \%$ of others were over 35 . Table 3 showed the results of statistics on indoor air quality satisfaction.

It showed the worst satisfaction with the indoor air quality of the underground malls, and it was A-2 $>$ A$3>$ A-1. The next followed by the snack cities, it was $\mathrm{C}-1>\mathrm{C}-2>\mathrm{C}-3$. While the underground electronic cities 
Table 3. Results of indoor air quality satisfaction in different underground buildings.

\begin{tabular}{|c|c|c|c|c|c|c|c|c|c|}
\hline \multirow{2}{*}{ Location } & \multicolumn{3}{|c|}{ Underground shopping malls } & \multicolumn{3}{c|}{ Underground electronic cities } & \multicolumn{4}{c|}{ Underground snack cities } \\
\cline { 2 - 11 } & A-1 & A-2 & A-3 & B-1 & B-2 & B-3 & C-1 & C-2 & C-3 \\
\hline S (Summer) & -1.92 & -1.37 & -1.64 & 1.06 & 0.72 & 1.22 & -0.46 & -0.83 & -1.11 \\
\hline S (Winter) & -1.78 & -1.52 & -1.38 & 0.91 & 0.64 & 1.29 & 0.09 & -1.02 & -1.2 \\
\hline
\end{tabular}

were satisfied, it was B-3>B-1>B-2. The summer and winter satisfaction rates were shown in Figs 3-7.

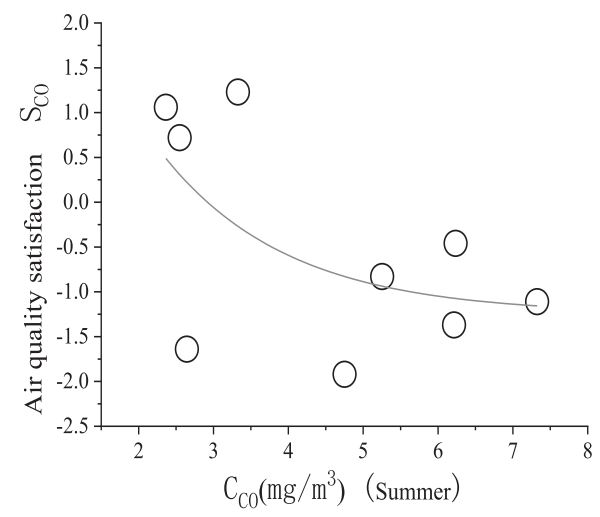

Fig. 3. Relationship between air quality satisfaction and CO.

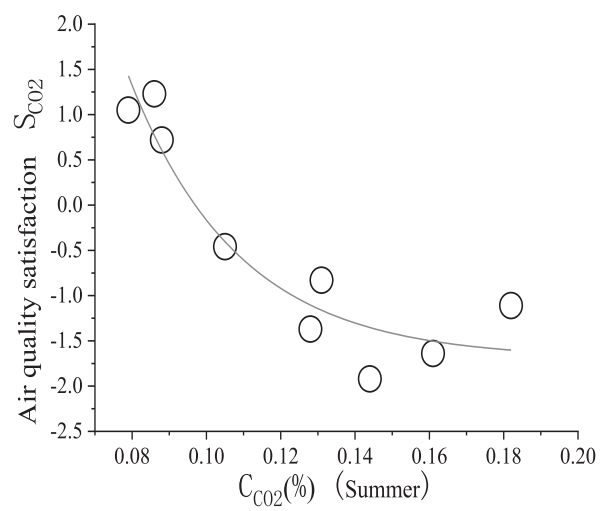

Fig. 4. Relationship between air quality satisfaction and $\mathrm{CO}_{2}$.

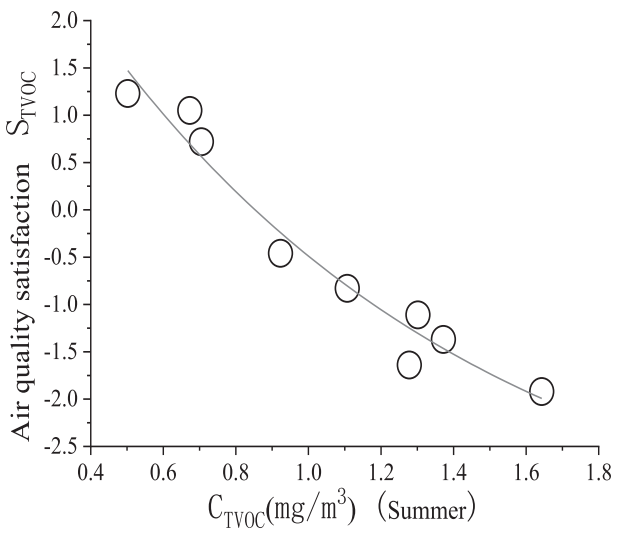

Fig. 5. Relationship between air quality satisfaction and TVOC.
Fig. 3 shows the relationship between human satisfaction and $\mathrm{CO}$ showed no correlation (the
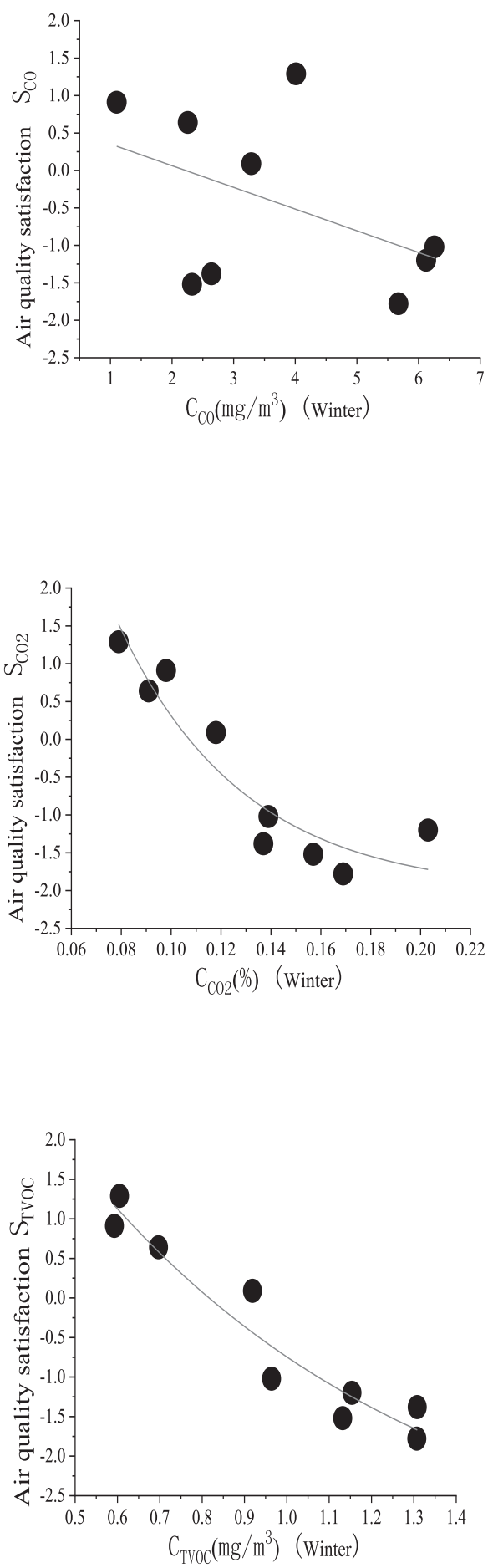

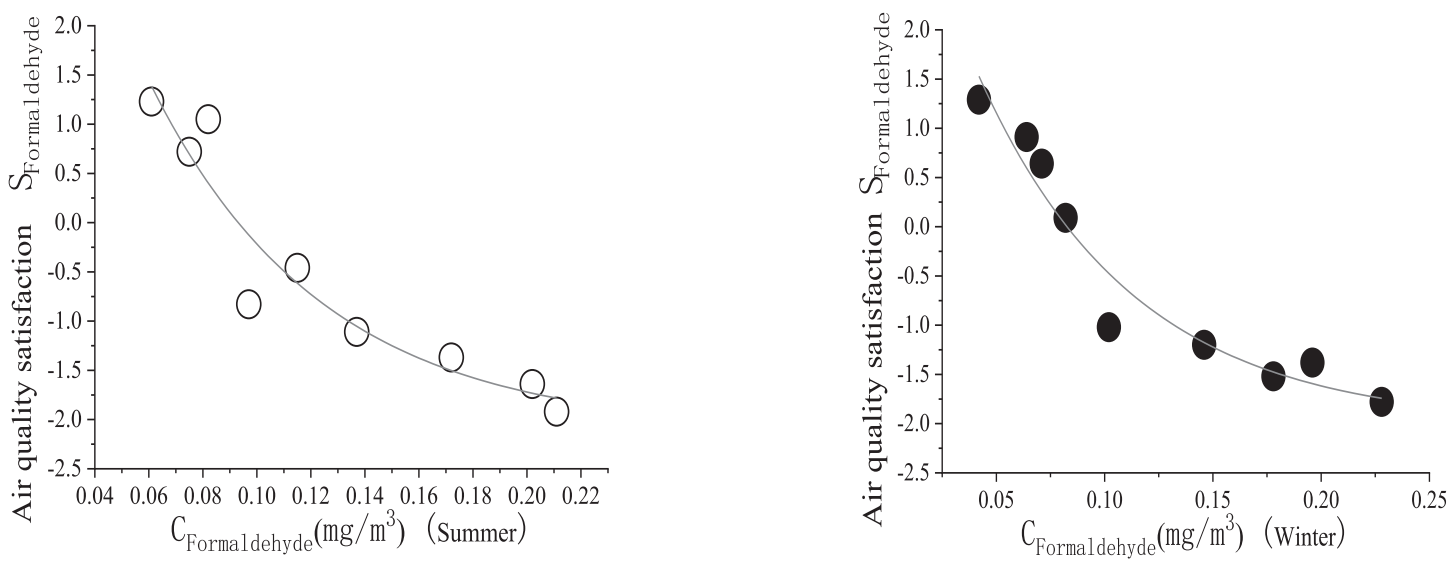

Fig. 6. Relationship between air quality satisfaction and formaldehyde.
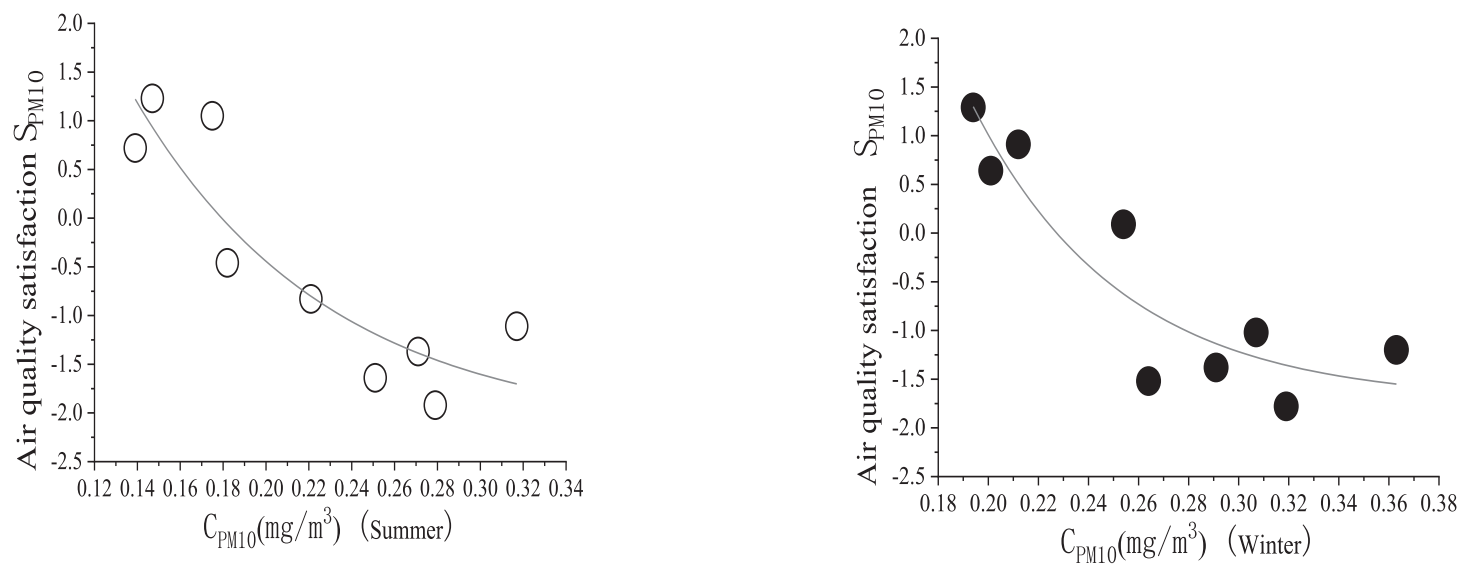

Fig. 7. Relationship between air quality satisfaction and $\mathrm{PM}_{10}$.

correlation coefficients were only 0.313 and 0.216 , respectively). Figs 4 to 7 showed there was a good correlation between human satisfaction and formaldehyde, $\mathrm{PM}_{10}, \mathrm{CO}_{2}$, and TVOC. The correlation between human satisfaction and TVOC in summer was better than in winter. The correlation between human satisfaction and formaldehyde in winter was better than in summer. The correlation between human satisfaction and $\mathrm{PM}_{10}$ in winter was better than in summer. The correlation between human satisfaction and $\mathrm{CO}_{2}$ in summer was better than in winter. Specific features were shown in Table 4.

Table 4 shows human satisfaction limit for $\mathrm{CO}_{2}$ was close to the standard value [24]. It was $0.099 \%$ (summer) $<0.10 \%<0.106 \%$ (winter). Satisfaction limit for TVOC was higher than the standard value [24].

Table 4. Results of satisfaction fitting.

\begin{tabular}{|c|c|c|c|c|c|}
\hline Pollutants & Time & Fitting formula & Correlation & $y=0$ & Standard \\
\hline \multirow{2}{*}{$\mathrm{CO}_{2}$} & Summer & $\mathrm{y}=45.7 * \exp (\mathrm{x} /-0.03)-1.70$ & $\mathrm{R}^{2}=0.901$ & 0.099 & \multirow{2}{*}{$0.10 \%$} \\
\hline & Winter & $y=17 * \exp (x /-0.05)-2.02$ & $\mathrm{R}^{2}=0.887$ & 0.106 & \\
\hline \multirow{2}{*}{ TVOC } & Summer & $\mathrm{y}=8.46^{*} \exp (\mathrm{x} /-1.08)-3.85$ & $\mathrm{R}^{2}=0.959$ & 0.85 & \multirow{2}{*}{$0.6 \mathrm{mg} / \mathrm{m}^{3}$} \\
\hline & Winter & $y=10.1 * \exp (x /-0.8)-3.65$ & $\mathrm{R}^{2}=0.931$ & 0.815 & \\
\hline \multirow{2}{*}{ Formaldehyde } & Summer & $\mathrm{y}=9.12 * \exp (\mathrm{x} /-0.06)-2.12$ & $\mathrm{R}^{2}=0.911$ & 0.087 & \multirow{2}{*}{$0.1 \mathrm{mg} / \mathrm{m}^{3}$} \\
\hline & Winter & $\mathrm{y}=6.35^{*} \exp (\mathrm{x} /-0.07)-2.01$ & $\mathrm{R}^{2}=0.946$ & 0.08 & \\
\hline \multirow{2}{*}{$\mathrm{PM}_{10}$} & Summer & $\mathrm{y}=15.7 * \exp (\mathrm{x} /-0.09)-2.18$ & $\mathrm{R}^{2 \mathrm{v}}=0.811$ & 0.178 & \multirow{2}{*}{$0.15 \mathrm{mg} / \mathrm{m}^{3}$} \\
\hline & Winter & $y=79.2 * \exp (x /-0.06)-1.73$ & $\mathrm{R}^{2}=0.843$ & 0.229 & \\
\hline
\end{tabular}


It was $0.815 \mathrm{mg} / \mathrm{m}^{3}$ (winter) $<0.6 \mathrm{mg} / \mathrm{m}^{3}<0.85 \mathrm{mg} / \mathrm{m}^{3}$ (summer). Satisfaction limit for formaldehyde was lower than the standard value [24]. It was $0.08 \mathrm{mg} / \mathrm{m}^{3}$ (winter) $<0.1 \mathrm{mg} / \mathrm{m}^{3}<0.087 \mathrm{mg} / \mathrm{m}^{3} \quad$ (summer). Satisfaction limit for $\mathrm{PM}_{10}$ was slightly higher than the standard value [24]. It was $0.178 \mathrm{mg} / \mathrm{m}^{3}$ (summer) $<0.15 \mathrm{mg} / \mathrm{m}^{3}$ $<0.229 \mathrm{mg} / \mathrm{m}^{3}$ (winter). The results of $\mathrm{PM}_{10}$ in winter and in summer were much different, which might be with the colorlessness and odor of particulate matters, and and it lead to differences in results [31]. The results showed the most prominent pollutants in underground buildings were TVOC and $\mathrm{PM}_{10}$, but formaldehyde should also be paid attention. It would provide a reference to build a good condition in underground buildings in the future.

\section{Conclusions}

In this paper, the indoor air quality was tested of nine underground buildings in Xi'an, and the finding out indoor staff's satisfaction were also conducted to get the following preliminary conclusions:

1. The concentrations of four pollutants except for CO were all exceeding the standard. The most serious pollutions were in the underground shopping malls, followed by underground snack cities. The lightest pollutions were in the underground electronic cities. The most prominent pollutants were $\mathrm{PM}_{10}$ and TVOC, followed by formaldehyde.

2. Indoor air quality of underground shopping malls was the worst satisfaction with people, followed by underground snack cities. While the underground electronic cities were satisfied.

3. Satisfaction limit of formaldehyde was lower than the standard value. Satisfaction limit of TVOC was higher than the standard value. Satisfaction limit of $\mathrm{PM}_{10}$ was slightly higher than the standard value. Satisfaction limit of $\mathrm{CO}_{2}$ was close with the standard value. Both of the pollutant concentrations and human subjective feelings should need to consider comprehensively for indoor air quality, and it would contribute to develop widely and application of underground buildings.

\section{Conflict of Interest}

The authors declare no conflict of interest

\section{References}

1. BOBYLEV N. Underground space as an urban indicator: Measuring use of subsurface. Tunnelling and Underground Space Technology, 55, 46, 2016.

2. ZHEN Q. Development and Utilization of Urban Underground Space. IOP Conference Series: Earth and Environmental Science, 242, 052059, 2019.

3. HE X.J., LI A.G., NING Y.T. Optimization of outdoor design temperature for summer ventilation for undersea road tunnel using field measurement and statistics. Building and Environment, 167, 106457, 2020.

4. WEN Y.M., LENG J.W., SHEN X.B., HAN G., SUN L.J., YU F. Environmental and Health Effects of Ventilation in Subway Stations: A Literature Review. International Journal of Environmental Research and Public Health, 17 (3), 1084, 2020

5. MAO P., LI J., XIONG L.L., WANG R.B., WANG X., TAN Y.T., LI H.Y. Characterization of Urban Subway Microenvironment Exposure - A Case of Nanjing in China. International Journal of Environmental Research and Public Health, 16 (4), 625, 2019.

6. ZHANG P. Development Value and Future Trend of Urban Underground Street. Current Urban Studies, 7 (1), 23, 2019.

7. XU S.S. Development and use of underground space for entertainment and cultural activities in the People's Republic of China. Tunnelling and Underground Space Technology, 2 (3), 272, 1987.

8. LI A.G., KOSONEN R., MELIKOV A., YANG B., OLOFSSON T., SORENSEN B., ZHANG L.H., CUI P., HAN O. Ventilation and environmental control of underground spaces: a short review. E3S Web of Conferences, 111, 01039, 2019.

9. PAN S., DU S.S., WANG X.R., ZHANG X.X., XIA L., LIU J.P., PEI F., WEI Y.X. Analysis and interpretation of the particulate matter $\left(\mathrm{PM}_{10}\right.$ and $\left.\mathrm{PM}_{2.5}\right)$ concentrations at the subway stations in Beijing, China. Sustainable Cities and Society, 45, 373, 2018.

10. TAO H.T., FAN Y.S., LI X.Q., ZHANG Z.R., HOU W.S. Investigation of formaldehyde and TVOC in underground malls in Xi'an, China: Concentrations, sources, and affecting factors. Building and Environment, 85, 90, 2015.

11. PENG S.B., CHEN Q.K., GUO B.Y., PEI G.H. Carbon monoxide diffusion and ventilation in underground garage. Applied ecology and environmental research, 17 (4), 9078, 2019.

12. ALGHAMDI M.A. Characteristics and Risk Assessment of Heavy Metals in Airborne PM $_{10}$ from a Residential Area of Northern Jeddah City, Saudi Arabia. Polish Journal of Environmental Studies, 25 (3), 939, 2016.

13. WANG M.S., CAO J.L., GUI C.L., XU Z.F., SONG D.Y. The Characteristics of Spatiotemporal Distribution of $\mathrm{PM}_{2.5}$ in Henan Province, China. Polish journal of environmental studies, 26 (6), 2789, 2017.

14. ZHOU J., YOU Y., BAI Z.P., HU Y.D., ZHANG J.F., ZHANG N. Health risk assessment of personal inhalation exposure to volatile organic compounds in Tianjin, China. Science of the Total Environment, 409 (3), 457, 2011.

15. BARI M.A., KINDZIERSKI W.B. Ambient volatile organic compounds (VOCs) in Calgary, Alberta: Sources and screening health risk assessment. Science of the Total Environment, 631-632, 636, 2018.

16. BILLIONNET C., GAY E., KIRCHNERD S., LEYNAERT B., ANNESI-MAESANO I. Quantitative assessments of indoor air pollution and respiratory health in a populationbased sample of French dwellings. Environmental Research, 111, 432, 2011.

17. CHEN Y.Y., SUNG F.C., CHEN M.L., MAO I.F., LU C.Y. Indoor Air Quality in the Metro System in North Taiwan. International Journal of Environmental Research and Public Health, 13 (12), 1200, 2016.

18. SHANG Y.Z. Research on indoor air quality in large shopping malls and ventilation improvement strategies. Chongqing University, Chongqing, 2017. 
19. ZHAO M.J., KIM Y.S., SREBRIC J. Occupant perceptions and a health outcome in retail stores. Building and Environment, 93, 391, 2015.

20. SHANG Y.Z., LI B.Z., BALDWIN A.N., DING Y., YU W., CHENG L. Investigation of indoor air quality in shopping malls during summer in Western China using subjective survey and field measurement. Building and Environment, 108, 9, 2016.

21. LI Y., GENG S.B., YUAN Y.P., WANG J., ZHANG X.S. Evaluation of climatic zones and field study on thermal comfort for underground engineering in China during summer. Sustainable Cities and Society, 43, 427, 2018.

22. BSISO 16814:2008. Building environment design-Indoor air quality-Methods of expressing the quality of indoor air for human occupancy, 2008.

23. CHEN Z.G., CHEN C., WEI S., LIU Z.J., CAO G.Q., DU Y.W., LI G.Z., ZHU J.H., MA Y.M., WANG Y.F. Determination of key parameters (air exchange rate, penetration factor and deposition rate) for selecting residential air cleaners under different window airtightness levels. Sustainable Cities and Society, 56, $102087,2020$.

24. GB/T 18883-2002. Indoor air quality standard. Standards Press of China, 2002.

25. GB/T 17216-2012. Hygienic requirements for peacetime utilization of civil air defence works. Standards Press of China, 2012.
26. ZHAO F.L. Experimental research and evaluation on indoor air quality of typical urban underground buildings. Xi'an University of Architecture and Technology, Xi'an, 2015.

27. SHEN J.M. Indoor air quality evaluation. HVAC, 27, 23, 1997.

28. ZHENG W.Y. Evaluation of indoor air quality in commercial buildings in Chongqing. Chongqing University, Chongqing, 2016.

29. LIU X.Z., WANG G.Z., LIU L.H. The analysis of pollution level of $\mathrm{PM}_{10}$ and $\mathrm{PM}_{2.5}$ in large and moderate scale shopping centres. Journal of Environment and Health, 23 (4), 337, 2006.

30. LEE S.C., LI W.M., CHAN L.Y. Indoor air quality at restaurants with different styles of cooking in metropolitan Hong Kong. Science of the Total Environment, 279 (1-3), 188, 2001.

31. YANG K.D. Environmental Hygiene 8th Edition. Beijing: People's Medical Publishing House, 468, 2017.

32. ZHANG X., FAN Y.S., TIAN G.J., WANG H., ZHANG H.L., XIE W. Influence of Fiber Diameter on Filtration Performance of Polyester Fibers. Thermal Science, 23 (4), 2294, 2019.

33. ZHANG X., FAN Y.S., WANG H., ZHANG J.X., WEI S.X., TIAN G.J., XIE W. Experimental study on the structure and properties of modified nonwoven filter fibers by impregnation with carbon black. Journal of Engineered Fibers and Fabrics, 15, 4, 2020. 